\title{
Participation of visitors in the management design of protected natural areas
}

\author{
M. F. Schmitz, D. Ruiz-Labourdette, P. F. Sañudo, C. Montes \\ \& F. D. Pineda \\ University Complutense and Autónoma of Madrid, Spain
}

\begin{abstract}
Providing a natural area with protection status involves many types of considerations and interests. Among these are criteria of an ecological, naturalistic, aesthetic, cultural and educational nature. The precise layout of these spaces also brings political standpoints into play, which are often at loggerheads with the recommendations for the application of these criteria. A study conducted in central Spain for the declaration, demarcation and internal sectoring of the future Guadarrama National Park introduces new methodological aspects. The aesthetic qualities of the landscape have been described both by experts and with the use of evaluations (questionnaires answered by the different types of visitors to the region of the future Park). An essential objective of protected spaces is to ensure that the visitors enjoy nature through environmental education. Otherwise, nature conservation would be meaningless. In the current paper, we detected serious problems related to appraising the landscape and sectoring the space for the management of the park. Depending on the estimated reaction in each spatial sector in relation to different rural activities and tourism uses, the team of experts obtained maps of the Park that did not tally with those based upon the demands of the different types of visitors. Aside from the conservation of unarguably fragile sectors, which require strict protection, the aforementioned demands give rise to serious doubts in the use and management of protected areas. The paper discusses different alternatives.

Keywords: Guadarrama National Park, landscape ecology, landscape planning, visitor's preferences.
\end{abstract}




\section{Introduction}

An added value of traditional rural landscapes involves the growing demand for tourism. Indeed, this is yet another quality product of those contained therein (Pineda \& Brebbia [1]). These circumstances invite us to rationalise and plan the development of new uses of the territory related to leisure, recreation and cultural tourism (German Federal Agency for Nature Conservation [2], Fernández et al. [3]). In the cultural landscape, the interaction among ecological processes, socio-economic structure and cultural heritage eventually become conditioned, too, by the new demands for tourism (De Graaf et al. [4], Musters et al. [5], Schmitz et al. [6]).

Furthermore, the effect of tourism on landscapes is becoming increasingly significant, as tourists tend to seek particularly fragile areas. In these places, which tend to abound in protected natural areas, tourism can nevertheless constitute a profitable investment for management, habitat protection, conservation of biodiversity, revitalisation of agricultural production and improved living standards of the local population (Klein et al. [7], Goodwin [8], Hjalager [9]). This is vital for establishing links between the recreational use of nature and the conservation thereof and contributes to the maintenance of traditional uses and landscapes (King and Stewart [10]).

The current paper deals with how both the experts' appraisal of the different types of landscapes and the opinion of the different categories of visitors in relation to the value of these landscapes should be considered in the development of leisure and recreational activities linked to tourism in protected natural areas. These visitors, after all, are the users of this recreation. Both rational and emotional aspects come into play in the appraisal of the landscape, and two analytical (Atauri et al. [11], Schmitz et al. [12]) and synthetic (González Bernáldez et al. [13], Gallardo et al. [14]) parameters can be employed to this end; we chose the former ones for this study.

This paper's origins lie in the recognition of the fact that the Guadarrama mountains, in central Spain and very close to a big city like Madrid, visited by many tourists, require a sensible model of tourism. Knowledge of the visitors' specific preferences will enable the recreational use to be managed according to the territory's carrying capacity, to its characteristics and to its possibilities for certain types of activities. One of the objectives of environmental management should involve meeting the requirements and expectations of potential users (Schmitz et al. [6]). The aforementioned considerations are therefore relevant in the design and creation of protected natural areas, especially if we consider the possibilities for enjoyment by visitors.

\section{Study area}

We studied the mountainous region of Guadarrama, in central Spain, where the authorities have provided for the creation of a new National Park. The southern border of this park (900 m asl) is barely $40 \mathrm{~km}$ from the city of Madrid (Fig. 1). 
At their highest point, these mountains, comprising granites, gneisses and small traces of limestone, reach to just over $2,400 \mathrm{~m}$. The general climate is continental Mediterranean, which gives rise to unique enclaves for flora, highly diverse plant communities and different cultural landscapes. Among the latter are dehesas (MaB [15]) and bocage-type countryside (Burel and Baudry [16]), along with Holm oak, oak and Scots pine forests and mountainside and high altitude scrub and pastures.

The area has around 60,000 inhabitants. In the last few decades, there have been big changes in the landscape resulting from radical socio-economic change (Valenzuela [17], García Delgado [18]). There is now widespread development for housing of spaces secularly reserved for traditional uses, above all forestry and grazing.

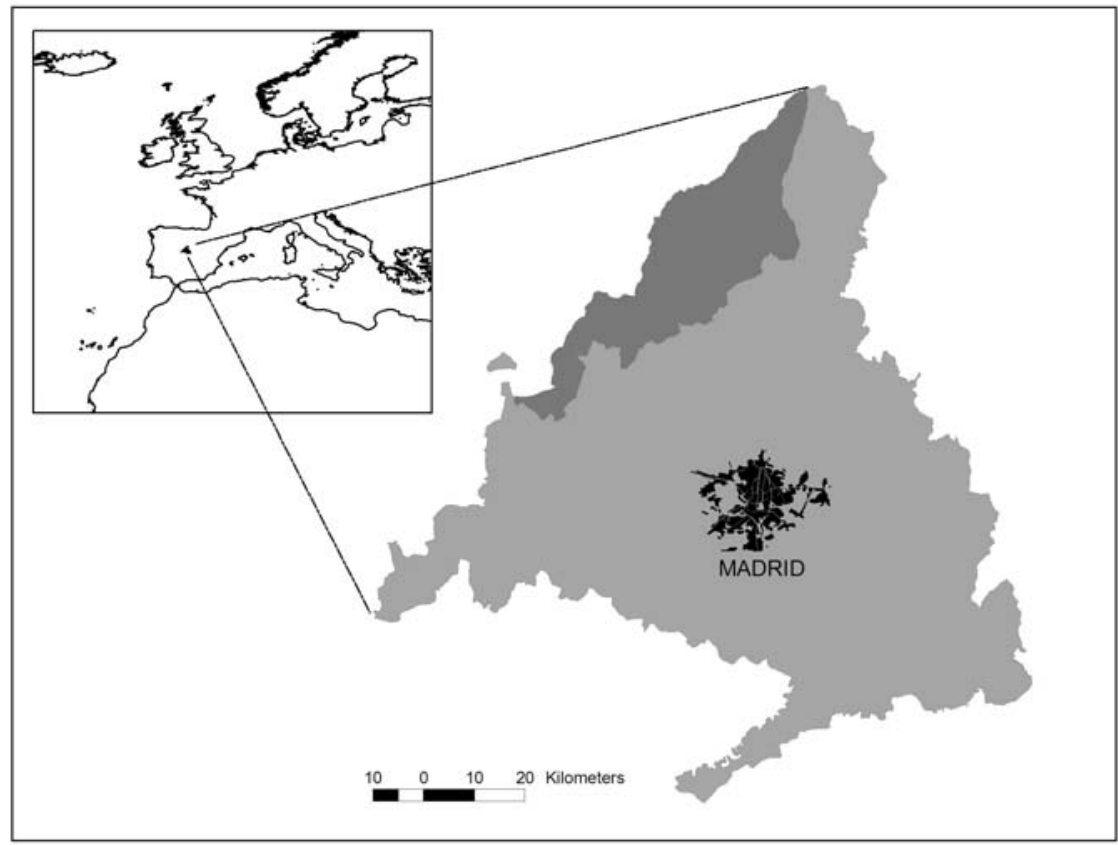

Figure 1: Location of the Guadarrama mountains in the Madrid region (central Spain).

\section{Method}

The authors of this paper participated in the design of the limits of the future Guadarrama National Park. To this end, we analysed the territory considering three different themes, expressed in the form of maps ('mesoclimate', 'physiography', 'soil', 'convergence and divergence of surface water flows', 'vegetation', 'fauna' and 'visual quality of the landscape'). The aim of this 
analysis was to appraise the environmental quality ('current value') of each sector into which the territory can be divided according to each of these themes, and to use this to establish the territory's carrying capacity in relation to the different activities compatible with the concept of a National Park. The procedure followed integrates the partial values of the environmental quality of each theme into a global appraisal and is based upon the IRAMS method (Impact Recording and Minimization System) (González Bernáldez et al. [19]; Sancho et al. [20]); Montalvo et al. [21]). This method considers the weighted sum of the values assigned to the different spatial sectors comprising each of the themes (partial values), which are subsequently used to obtain a global appraisal of the carrying capacity.

Different team specialists conducted the appraisal of the sectors into which the territory was divided according to each theme, but in the case of the 'visual quality of the landscape', apart from this appraisal, we analysed the visitors' preferences according to the procedure described by Schmitz et al. [12]. Thus, for the landscape theme, we obtained different appraisal maps of the same territory: sectoring and appraisal of the landscape units conducted by the team's specialists and sectoring and appraisal of the landscape by the visitors.

\subsection{Sectoring and appraisal of landscape units by the team of experts}

We demarcated visual basins using a network of points distributed regularly throughout the territory. We first appraised the area of each visual basin and then the quality thereof according to the 'naturalness of the vegetation' -a generic concept obtained by comparing the current plant cover and land uses of the territory with the potential vegetation, that is, what would exist in the territory depending on the tolerance of the plant communities to mesoclimatic, lithological and geomorphological variations in the area with no human intervention-. The units of the corresponding potential vegetation map were provided by the team of phytosociologists following the work of Rivas-Martínez [22]. We also took into consideration the fragmentation of the territory resulting from asphalted roads, each visual basin being assigned a degree of fragmentation. We finally obtained six landscape quality units in the whole study area.

\subsection{Sectoring and appraisal of landscape units by the visitors}

In order to analyse the landscape preferences of the visitors to the study area, we conducted 878 detailed questionnaires enquiring about these preferences. We used these to conduct multivariate classification analyses, which enabled us to detect the landscape units differentiated by these analyses and by the different types of visitors. The procedure followed is described in Schmitz et al. [12]. This basically consists of sectoring the territory according to the types of landscapes the visitors are capable of differentiating and of establishing their appraisal of these. 


\section{Results and discussion}

Figure 2(1) shows the map of landscape visual quality sectors according to how these were appraised by the team of experts. Nine categories were differentiated.

Moreover, the classification analysis based upon the questionnaires enabled us to detect five types of visitors: i) 'indifferent' (31,55\% of the informing subjects), with no obvious interest in nature and whose main objective is to enjoy their spare time; ii) 'non-cultural generalists' $(7,63 \%)$, with little interest in the territory's cultural offer and motivated by leisure activities close to their habitual residence; iii) 'rural generalists' $(32,69 \%)$, interested in natural values and the rural environment; iv) 'sports naturalists' $(11,50 \%)$, mainly interested in open-air sports, and v) 'rural naturalists' $(16,63 \%)$, interested in natural and cultural landscapes.

Only four sectors were perceived by the group of informing subjects: a) high mountain; b) mid-mountain and foothills; c) low mountain and d) upper and lower zones of mountain valleys. Table 1 shows the relative appraisal of these four types of landscapes by the five types of visitors detected. The cartography thereof is shown in Figure 3.

Table 1 shows a gradient in the values assigned by the different types of visitors to the four types of landscapes they jointly differentiated. These values range from the lowest and medium ones, predominating for 'indifferent' and 'non-cultural generalists' visitors, to high and very high values, characterising the 'rural-naturalists'. Low mountain is the zone preferred by the 'rural cultural generalists' and by the two groups of 'naturalists'. The 'rural naturalists' also assign high values to the area comprising the foothills and mid-mountain zone and the upper zones and mountain valleys. It is interesting to note that the landscape unit least valued by the group of visitors to the study area is the high mountain zone.

The results highlight a certain contradiction in the appraisal of the landscape, which is nevertheless vital with regard to estimating the territory's capacity to accommodate activities compatible with National Park status. The team specialists created a landscape map with more categories than what the visitors detected, and based upon clearly objective criteria. Their appraisal coincided to a certain degree with that of some visitors, but clearly differs from that of others. Thus, the rural naturalists coincide with the specialists on considering the foothills and mid-mountain zones as valuable landscapes of the future Park, but differ in their appraisal of the remaining territory. The high mountain landscapes are highly appraised by the specialists, a fact that differs very much from the opinion of the group of visitors (the opinion of the 'nature/rural' visitors differs somewhat less). The greatest coincidences in the low score of the landscape occurs in the Upper and lower zones of mountain valleys between the specialists and the 'indifferent' visitors and the 'non-cultural generalists' visitors, who do not precisely show any great love of nature in the questionnaires. There is no coincidence in any sector of the territory between the high score given by the specialists to certain landscapes and the appraisal of any of the types of visitors. 
The group of visitors gave the highest score to the low mountain area (the specialists gave this a medium value). Similar considerations could be made of other comparisons -Table 2 and Figs. 2(2) and 3.

The Irams procedure enabled us to estimate the cost or 'environmental impact' of the different human activities in the territory, in order to protect the more fragile sectors and, in this case, to establish the correct limits of the future Park. Within these limits, internal sectoring based on Irams enabled us to establish the most appropriate uses and type of management for the Park. In order to calculate the environmental impact, a previous appraisal of the themes making up the study area (partial appraisals). This appraisal can be considered to be unarguable in certain cases -for instance, that corresponding to the different sectors into which the experts in 'fauna' divide the territory or the sectors into which it is classified by the agricultural experts according to criteria relating to 'land productivity'-, but it is a subjective concept in the case of landscapes. Indeed, the attractiveness of a landscape and the consequent appraisal thereof depend on the opinion of the observer (González-Bernáldez et al. [13]).

Table 1: $\quad$ Relative appraisal by the visitors of the types of landscape they perceived. The procedure followed is described in Schmitz et al. [12]. Low appraisal (L) -variation range from -1.397 to $-0.383-$, medium $(\mathrm{M})$-from -0.384 to $0.62-$, high $(\mathrm{H})$-from 0.62 to $1.642-$ and very high ( $\mathrm{VH})$-from 1.643 to $2.656-$.

\begin{tabular}{|c|c|c|}
\hline Type of Visitor & Type of landscape & Appraisal \\
\hline \multirow[t]{4}{*}{ 'Indifferent' } & High mountain & $-1,341 \mathrm{~L}$ \\
\hline & Foothills and mid-mountain & $-1,024 \mathrm{~L}$ \\
\hline & Low mountain & $-0,536 \mathrm{~L}$ \\
\hline & $\begin{array}{l}\text { Upper and lower zones of mountain } \\
\text { valleys }\end{array}$ & $-1,495 \mathrm{~L}$ \\
\hline \multirow{4}{*}{$\begin{array}{l}\text { 'Non-cultural } \\
\text { generalists' }\end{array}$} & High mountain & $-0,762 \mathrm{~L}$ \\
\hline & Foothills and mid-mountain & $-0,293 \mathrm{~L}$ \\
\hline & Low mountain & $0,557 \mathrm{M}$ \\
\hline & $\begin{array}{l}\text { Upper and lower zones of mountain } \\
\text { valleys }\end{array}$ & $-0,556 \mathrm{~L}$ \\
\hline \multirow{4}{*}{$\begin{array}{l}\text { 'Rural-cultural } \\
\text { generalists' }\end{array}$} & High mountain & $-0,891 \mathrm{~L}$ \\
\hline & Foothills and mid-mountain & $-0,28 \mathrm{M}$ \\
\hline & Low mountain & $0,647 \mathrm{H}$ \\
\hline & $\begin{array}{l}\text { Upper and lower zones of mountain } \\
\text { valleys }\end{array}$ & $-0,471 \mathrm{M}$ \\
\hline \multirow{4}{*}{$\begin{array}{l}\text { 'Sports } \\
\text { naturalists' }\end{array}$} & High mountain & $-0,41 \mathrm{~L}$ \\
\hline & Foothills and mid-mountain & $0,301 \mathrm{M}$ \\
\hline & Low mountain & $1,582 \mathrm{H}$ \\
\hline & $\begin{array}{l}\text { Upper and lower zones of mountain } \\
\text { valleys }\end{array}$ & $0,142 \mathrm{M}$ \\
\hline \multirow{4}{*}{$\begin{array}{l}\text { 'Rural } \\
\text { naturalists' }\end{array}$} & High mountain & $0,556 \mathrm{M}$ \\
\hline & Foothills and mid-mountain & $0,986 \mathrm{H}$ \\
\hline & Low mountain & $2,508 \mathrm{VH}$ \\
\hline & $\begin{array}{l}\text { Upper and lower zones of mountain } \\
\text { valleys }\end{array}$ & $0,725 \mathrm{H}$ \\
\hline
\end{tabular}



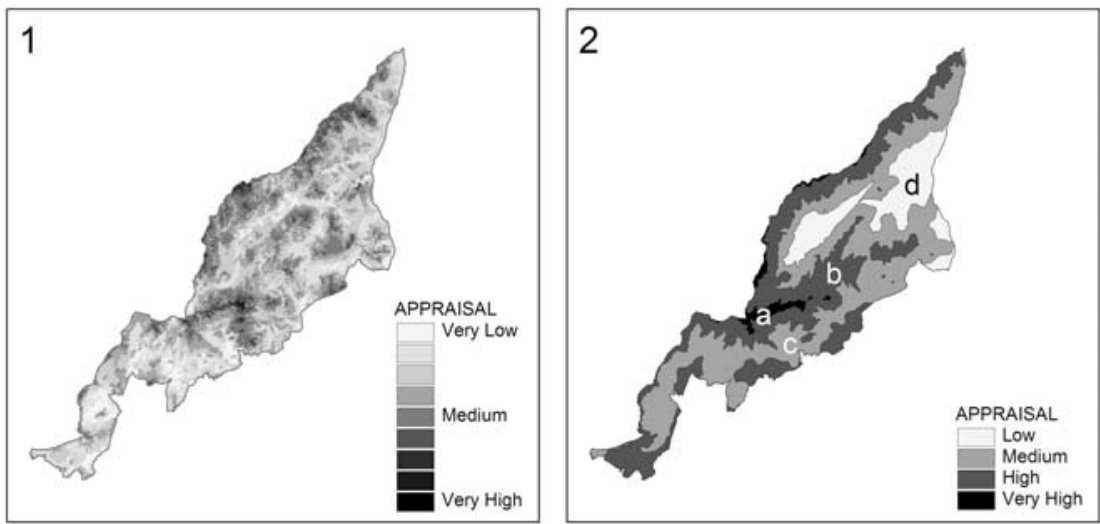

Figure 2: 1. Map of visual quality landscape sectors appraised by the specialists and divided into nine classes. 2. Map with the four sectors differentiated by the visitors and appraised by the specialists.
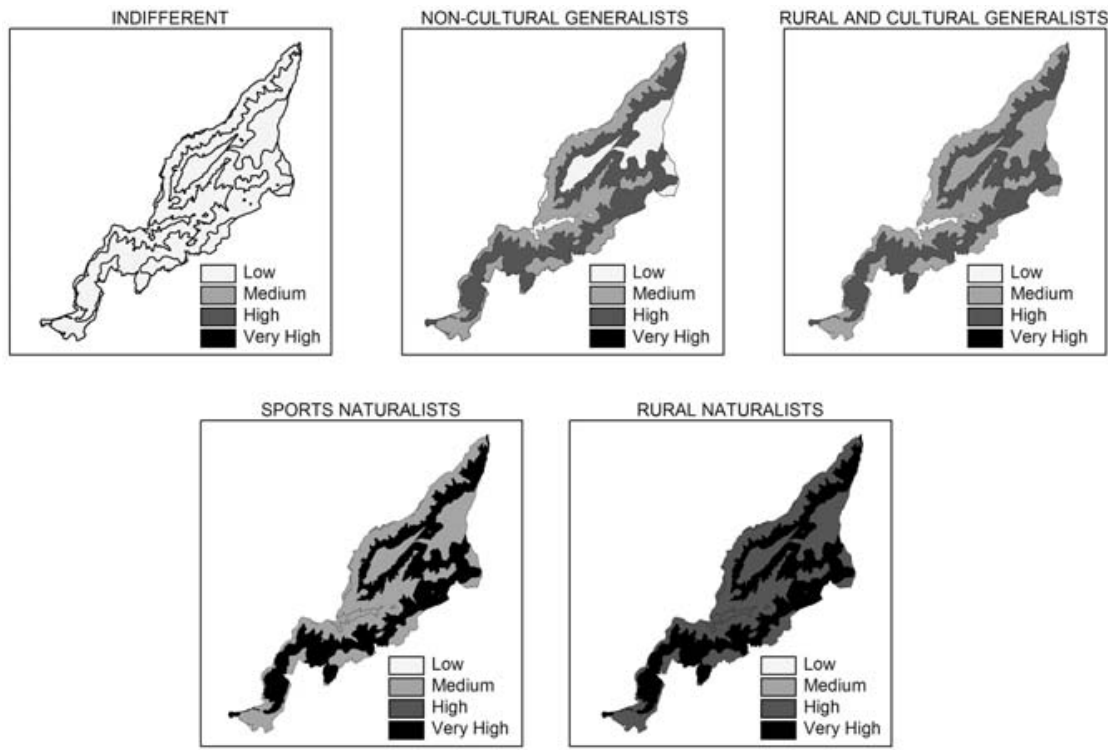

Figure 3: Landscape sectors detected using the visitors' answers to the questionnaires and appraisal of these sectors by the five types of visitors identified.

The problem involved in conserving a landscape relates to a consensus between the users of the resource -the visitors- and the management experts. In the results obtained herein, these users identify very few landscape types on appraising the aesthetic qualities of the territory. The experts, however, 
established numerous details and their scales of appraisal are much more detailed as a result of the procedure followed. It can nevertheless be said that the landscape resource contains subjective values.

Table 2: $\quad$ Appraisal of the landscape sectors by the specialists and by the four types of visitors identified (S: Specialists; I: Indifferent; NCG: Non-cultural generalists; RCG: Rural and cultural generalists; SN: Sports naturalists; RN: Rural naturalists). The sectors indicated are those perceived by the visitors. Coinciding appraisals are shown in brackets (D: discrepancy; C: coincidence).

\begin{tabular}{|c|c|c|c|c|c|c|}
\hline \multirow[t]{2}{*}{$\begin{array}{l}\text { Landscape } \\
\text { sectors }\end{array}$} & \multicolumn{6}{|c|}{$\begin{array}{l}\text { Appraisal by the observers and coincidence between the appraisals } \\
\text { made by specialists and visitors }\end{array}$} \\
\hline & $S$ & $I$ & $N C G$ & $R C G s$ & $S N$ & $R N$ \\
\hline $\begin{array}{l}\text { a) High } \\
\text { mountain }\end{array}$ & $\begin{array}{l}\text { Very } \\
\text { high }\end{array}$ & $\begin{array}{l}\text { Low } \\
\text { (high D) }\end{array}$ & $\begin{array}{l}\text { Low } \\
\text { (high D) }\end{array}$ & $\begin{array}{l}\text { Low } \\
\text { (high D) }\end{array}$ & $\begin{array}{c}\text { Low } \\
\text { (high D) }\end{array}$ & $\begin{array}{l}\text { Medium } \\
\text { (D) }\end{array}$ \\
\hline $\begin{array}{l}\text { b) Foothills } \\
\text { and mid- } \\
\text { mountain }\end{array}$ & High & $\begin{array}{l}\text { Low } \\
\text { (D) }\end{array}$ & $\begin{array}{l}\text { Low } \\
\text { (D) }\end{array}$ & $\begin{array}{l}\text { Medium } \\
\text { (certain C) }\end{array}$ & $\begin{array}{l}\text { Medium } \\
\text { (certain C) }\end{array}$ & $\begin{array}{l}\text { High } \\
(\mathrm{C})\end{array}$ \\
\hline $\begin{array}{l}\text { c) Low } \\
\text { mountain }\end{array}$ & Médium & $\begin{array}{c}\text { Low } \\
\text { (certain C) }\end{array}$ & $\begin{array}{l}\text { Medium } \\
\text { (C) }\end{array}$ & $\begin{array}{c}\text { High } \\
\text { (certain C) }\end{array}$ & $\begin{array}{c}\text { High } \\
\text { (certain C) }\end{array}$ & $\begin{array}{l}\text { Very high } \\
\text { (D) }\end{array}$ \\
\hline $\begin{array}{l}\text { d) Upper and } \\
\text { lower zones } \\
\text { of mountain } \\
\text { valleys }\end{array}$ & Low & Low (C) & $\begin{array}{l}\text { Low } \\
(C)\end{array}$ & $\begin{array}{l}\text { Medium } \\
\text { (certain C) }\end{array}$ & $\begin{array}{l}\text { Medium } \\
\text { (certain C) }\end{array}$ & $\begin{array}{l}\text { High } \\
\text { (D) }\end{array}$ \\
\hline
\end{tabular}

The conservation of nature and of the landscapes it contains constitutes a problem of consensus. Among the types of visitors detected, the 'indifferent' ones apparently show no great love of nature. The interest they show in merely enjoying their spare time as the objective of their visit probably gives them less say in the decisions taken regarding the conservation of landscapes than other visitors, such as the rural naturalists and rural and cultural generalists, who are clearly motivated by nature and the rural and cultural environments. The chances of reaching a consensus with these visitors are obviously greater than with the other types. Environmental education is a vital tool for nature conservation, although, among those involved, we cannot rule out the different types of visitors or the experts themselves. We therefore detected in the current paper serious doubts with regard to appraising the aesthetics of the landscape as an element for sectoring and managing a protected area.

\section{References}

[1] Pineda, F.D. \& Brevia, C.A. (eds.). Sustainable tourism, WIT Press: Southampton, 2004. 
[2] German Federal Agency for Nature Conservation (ed.). Biodiversity and Tourism. Conflicts on the World's Seacoasts and Strategies for Their Solution. Springer-Verlag, Berlin, Heidelberg and New York, 1997.

[3] Fernández, E., Rescia, A., Aguilera, P., Castro, H., Schmitz, M.F. \& Pineda, F.D. The natural offer of the landscape and the demand for tourism: a spatial analysis of visitors' preferences. Management Information Systems 2000. GIS and Remote Sensing, eds. C.A. Brebbia \& P. Pascolo, WIT Press: Southampton and Boston, 75-89, 2000.

[4] De Graaf, H.J., Musters, C.J.M. \& ter Keurs, W.J., Sustainable development: looking for new strategies. Ecological Economics, 16, pp. 205-216, 1996.

[5] Musters, C.J.M., de Graaf, H.J. \& ter Keurs, W.J., Defining socioenvironmental systems for sustainable development. Ecological Economics, 26, pp. 243-258, 1998.

[6] Schmitz, M., Pineda, F.D., Castro, H.C., de Aranzabal, I \& Aguilera, P., Cultural landscape and socioeconomic structure, Junta de Andalucía: Sevilla, 2005.

[7] Klein, M.L., Humphrey, S.R. \& Franklin, P.H., Effects of ecotourism on distribution of waterbirds in a wildlife refuge. Conservation Biology, 9, pp. 1454-1465, 1995.

[8] Goodwin, H. In pursuit of ecotourism. Biodiversity and Conservation, 5, pp. 277-291, 1996.

[9] Hjalager, A.M., Agricultural diversification into tourism. Tourism Management, 17, pp. 103-111, 1996.

[10] King, D.A. \& Stewart, W.P. Ecotourism and commodification: protecting people and places, Biodiversity and Conservation 5, pp. 293-305, 1996.

[11] Atauri, J.A., De Lucio, J.V. \& Gómez Sal, A. Ecological evaluation of landscapes in the Henares river basin, Spain. Publicationes Instituti Geographici Universitatis Tartuensis 92, pp.646-649, 2001.

[12] Schmitz, M.F., Fernández-Sañudo, P., de Aranzabal, I. \& Pineda, F.D., Visitor's valuation of natural and cultural landscapes: space-preferences coincidence analysis. Sustainable Tourism, eds. F.D. Pineda \& C.A. Brebbia, WIT Press: Southampton and Boston, pp. 308-317, 2004.

[13] González Bernáldez, F., Sancho Royo, F. \& García Novo, F. Analyse des réactions face au paysage naturel, Options Méditerranéennes, 17, pp. 66$81,1973$.

[14] Gallardo, D., Bernáldez, F.G., Ruiz, J.P. \& Abelló, R.P. Paysages préférés: divergences des jeunes en Espagne, L'Espace Géograpique, 1, pp. 27-37, 1989.

[15] MaB, (ed.). Dehesas y Sistemas Agro-silvo-pastorales, UnEsco: Madrid, 1991.

[16] Burel, F. \& Baudry, J. Ecologie du paysage: concepts, méthodes et applications, Lavoisier: Paris, 1999.

[17] Valenzuela, M. Urbanización y crisis rural la sierra de Madrid. Instituto de Estudios de Administración Local: Madrid, 1977. 
[18] García Delgado, J.L, (ed.). Estructura económica de Madrid, Civitas: Madrid, 2003.

[19] González Bernáldez, F., Sancho, F., \& Ródenas, M, Un système d'enregistrement et minimisation des impacts sur l'environment, IRAMS. Proc. of the Symposium informatique et environment, Arlon, 1974.

[20] Sancho, F., Alés, R.F., González Bernáldez, F. \& Rodenas, M. Sistema IRAMS de evaluación de alternativas de uso en la ordenación del territorio, Publicaciones Universidad de Sevilla: Sevilla, 1981.

[21] Montalvo, J., Ramírez Sanz, L., de Pablo, C.T., \& Pineda, F.D. Impact minimization through environmentally-based site selection: a multivariate approach, Journal of Environmental Management, 38, pp. 13-25, 1993.

[22] Rivas-Martínez, S. Mapa de series de vegetación de España y memoria, Ministerio de Agricultura, Pesca y Alimentación: Madrid, 1987. 